\title{
Pengaruh Perputaran Modal Kerja, Perputaran Kas, Perputaran Persediaan dan Perputaran Total Aset Terhadap Tingkat Profitabilitas Badan Usaha Milik Desa untuk Meningkatan Pendapatan Asli Desa Tahun 2019-2020 (Studi pada Badan Usaha Milik Desa Se-Kabupaten Buleleng)
}

\author{
Ni Luh Sucitra Dewi ${ }^{1 *}$, I Putu Gede Diatmika ${ }^{2}$ iD \\ ${ }^{123}$ Jurusan Ekonomi dan Akuntansi, Universitas Pendidikan Ganesha ,Singaraja, Indonesia \\ *niluhsucitradewi12@undiksha.ac.id ${ }^{{ }^{*}}$
}

\section{Abstrak}

Penelitian ini dilakukan pada BUMDes di Kabupaten Buleleng. Penelitian ini menggunakan populasi dengan jumlah populasi 16 BUMDes yang tersebar di wilayah Kabupaten Buleleng periode dalam penelitian ini adalah tahun 2019-2020. Penelitian ini bertujuan untuk mengetahui pengaruh tingkat perputaran modal kerja, perputaran kas, perputaran persediaan, dan perputaran total asset terhadap profitabilitas badan usaha milik desa di Kabupaten Buleleng. Penelitian ini menggunakan pendekatan kuantitatif. Teknik pengambilan sampel menggunakan purposive sampling dengan jumlah sampel 16 BUMDes. Jenis data yang digunakan adalah data sekunder. Metode pengumpulan data dilakukan dengan melalui dokumentasi. Teknik analisis data menggunakan analisis regresi linier berganda yang diolah menggunakan program SPSS 25 for Windows.Hasil penelitian menunjukkan bahwa : 1) Perputaran modal kerja berpengaruh negative tidak signifikan terhadap profitabilitas, (2) Perputaran kas berpengaruh positif signifikan terhadap profitabilitas, (3) perputaran persediaan berpengaruh positif tidak signifikan terhadap profitabilitas, (4) perputaran total asset berpengaruh negative signifikan terhadap profitabilitas. (5) pengaruh perputaran modal kerja, perputaran kas, perputaran persediaan dan perputaran total asset berpengaruh simultan terhadap profitabilitas. Hasil dari penelitian ini memberikan implikasi kepada pihak BUMDes dalam mengelola keuangan BUMDes agar lebih baik dan maksimal.

Kata Kunci : Perputaran Modal Kerja, Perputaran Kas, Perputaran Persediaan, Perputaran Total Aset, Profitablitas

\section{Abstract}

The study aimed at finding out the effect working capital turnover, cash turnover, inventory turnover, total asset turnover on the profitability of village-owned enterprises in Buleleng regency. This study was conducted based on a quantitative approach by involving 16 village-owned enterprises as the sampls which werw selected based on purposive sampling technique. The data were obtained from secondary sources by using documentation method, and analyzed by using a multiple regression supported by SPSS version 25.0 for Windows. The result indicated that (1) the level of working capital turnover had a negative and not significant on profitability, (2) the level of cash turnover had a positive and significant on profitability, (3) the level of inventory turnover had a positive and not significant on plofitability, (4) the level of total asset turnover had a negative and significant, and (5) the level of working capital turnover, cash turnover, inventory turnover, and total asset turnover of employee had a simultaneous significant effect on profitability. The results of this study have implications for BUMDes in managing BUMDes finances so that they are better and more optimal.

Keywords: Working Capital Turnover, Cash Turnover, Inventory Turnover, Total Asset Turnover, Profitability, and BUMDes

\section{Pendahuluan}

Undang-undang Nomor 6 Tahun 2014 tentang desa menyarankan desa untuk memiliki suatu badan yang berguna untuk memenuhi kebutuhan masyarakat, terutama kebutuhan pokok dan tersedianya sumber daya desa yang belum dimanfaatkan serta mampu mengelola

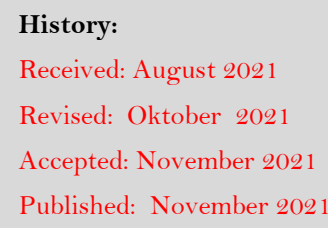

Licensed: This work is licensed under a Creative Commons Attribution 3.0 License

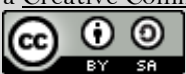


badan usaha sebagai asset penggerak ekonomi masyarakat. Menurut Salampessy (2011) bila suatu wilayah mampu dalam mengurus sendiri daerahnya dan sejalan dengan pendapatan asli daerah yang semakin tinggi, hal ini menunjukkan tingkat pertumbuhan ekonomi daerah tersebut juga semakin tinggi.

Menurut Badan Pusat Statistik (2021), Pendapatan Asli Desa (PAD) adalah penerimaan dari berbagai usaha pemerintah desa untuk mengumpulkan dana guna keperluan desa dalam membiayai kegiatan rutin/pembangunan. Pendapatan Asli Desa berasal dari penerimaan tanah kas desa, pasar/kios desa, pemandian umum yang diurus desa, daya tarik wisata, bangunan milik desa yang disewakan, kekayaan desa lainnya, swadaya dan partisipasi masyarakat dan gotong royong masyarakat. Termasuk juga penerimaan yang berasal dari pungutan desa dan hasil usaha desa.

Badan Usaha Milik Desa dalam ketentuan umum Peraturan Pemerintah 11 tahun 2021 tentang BUMDes adalah badan hukum yang didirikan oleh desa dan/atau bersama desadesa guna mengelola usaha, memanfaatkan aset, mengembangkan investasi dan produktivitas, menyediakan jasa pelayanan, dan/atau menyediakan jenis usaha lainnya untuk sebesar-besarnya kesejahteraan masyarakat Desa. BUMDes merupakan pilar kegiatan ekonomi di desa yang berfungsi sebagai lembaga sosial (social institution) dan komersial (commercial institution). BUMDes memiliki empat tujuan utama, yakni: meningkatkan perekonomian masyarakat desa, meningkatkan pendapatan masyarakat desa, mengoptimalkan potensi sumber daya alam untuk kebutuhan masyarakat dan menjadi alat pemerataan serta pertumbuhan ekonomi desa. Pemerintah saat ini sedang terus memperioritaskan peran BUMDes sebagai wadah yang dapat meningkatkan perekonomian dan pembangunan desa. Pengembangan basis ekonomi di pedesaan sudah lama dijalankan oleh pemerintah melalui berbagai program. Namun upaya itu belum membuahkan hasil yang memuaskan sebagaimana diinginkan bersama. Sistem dan mekanisme kelembagaan ekonomi di pedesaan tidak berjalan efektif dan berimplikasi pada ketergantungan terhadap bantuan pemerintah sehingga mematikan semangat kemandirian (Widyastuti, 2017).

Dalam mengelola dan mengintegrasikan unit-unit usaha yang dimiliki oleh BUMDes tersebut, maka kebutuhan akan informasi meningkat sejalan dengan perkembangan BUMDes tersebut. Semakin besar dan kompleks suatu organisasi, maka semakin besar pula kebutuhan akan informasi, pengembangan inovasi dan peningkatan efisiensi juga ditingkatkan untuk menghadap perkembangan ekonomi. Perusahaan harus mampu menyiapkan laporan keuangan dan memiliki dasar yang kuat dalam menjalankan operasionalnya dalam rangka memaksimalkan laba. Laporan keuagan pada dasarnya hasil dari proses akuntansi yang dapat digunakan sebagai alat untuk berkomunikasi dengan pihak-pihak yang berkepentingan dengan kondisi keuangan dan hasil operasi dari BUMDes. Pihak-pihak yang berkepentingan tersebut adalah manajemen, pemilik, kreditor, investor, penyalur, karyawan, lembaga pemerintah dan masyarakat umum.

Menurut Kasmir (2011 :135), margin laba bersih merupakan ukuran keuntungan dengan membandingkan antara laba setelah bunga dan pajak dibandingkan dengan penjualan. Ratio ini mengukur kemampuan BUMDes menghasilkan pendapatan bersihnya terhadap total penjualan bersih yang di capainya. Sesuai dengan tujuan yang hendak dicapai, terdapat beberapa jenis rasio profitabilitas yang dapat digunakan. Masing-masing jenis ratio profitabilitas digunakan untuk menilai serta mengukur posisi keuangan dalam suatu periode tententu. Menurut Kasmir (2014:115), jenis-jenis profitabilitas yang dapat digunakan adalah (1) Profit Margin on Sales, yaitu salah satu ratio yang digunakan untuk mengukur margin laba atas penjualan. (2) Return on Asset, yaitu ukuran kemampuan perusahaan dalam menghasilkan laba dengan semua aktiva yang dimiliki oleh perusahaandan (3) Return on 
Equity yaitu kemampuan perusahaan dalam menghasilkan keuntungan dengan modal sendiri. ROE digunakan untuk mengukur laba bersih sesudah oajak dengan modal sendiri.

Modal kerja adalah investasi perusahaan jangka pendek seperti kas, surat berharga, piutang dan inventory atau seluruh aktiva lancar. Mengingat pentingnya modal kerja di dalam perusahaan, manajer keuangan harus dapat merencanakan dengan baik besarnya jumlah modal kerja yang tepat dan sesuai dengan kebutuhan perusahaan, karena jika terjadi kelebihan atau kekurangan dana hal ini akan mempengaruhi tingkat profitabilitas perusahaan (Supriyadi dan Fazriani, 2011). Untuk menilai dan mengukur keefektifan dari modal kerja maka digunakan rasio perputaran modal kerja. Rasio perputaran modal kerja ialah Menurut Hery (2017:184), perputaran modal kerja adalah rasio yang digunakan untuk mengukur keektifan modal kerja (asset lancar) yang dimiliki perusahaan dalam menghasilkan penjualan. Rasio ini dihitung sebagai hasil bagi antara besarnya penjualan (tunai maupun kredit) dengan rata-rata asset lancar. Rasio ini menunjukkan beberapa kali modal kerja berputar dalam satu periode. Lamanya waktu rata-rata yang dibutuhkan modal kerja untuk setiap kali berputar Perputaran modal kerja yang rendah menunjukkan adanya kelebihan modal kerja yang mungkin disebabkan rendahnya perputaran persediaan, piutang atau adanya saldo kas yang terlalu besar. Demikian pula sebaliknya jika perputaran modal kerjanya tinggi, mungkin disebabkan tingginya perputaran persediaan, perputaran piutang atau saldo kas. Hal ini didukung dengan adanya penelitian Nopiana (2016) yang menyatakan bahwa tingkat perputaran modal berpengaruh positif dan signifikan terhadap profibatbilitas. Adapun tiga komponen modal kerja yaitu kas, piutang, dan persediaan. Ketiga komponen modal kerja tersebut dapat dikelola dengan cara yang berbeda untuk memaksimalkan profitabilitas atau untuk meningkatkan pertumbuhan perusahaan. Namun pada penelitian ini hanyalah akan menggunakan dua komponen modal kerja yaitu kas dan persediaan.

Kas adalah aset keuangan yang digunakan untuk kegiatan operasional perusahaan. Kas merupakan aset yang paling liquid karena dapat digunakan untuk membayar kewajiban perusahaan. kas merupakan alat pembayaran yang siap dan bebas dipergunakan untuk membiayai kegiatan entitas. Perputaran kas merupakan perbandingan antara penjualan dan kas, bisa disebut dengan rasio penjualan atas kas. Perputaran kas dapat diartikan berapa kali uang kas berputar dalam suatu periode tertentu melalui penjualan. Perputaran kas berguna untuk mengetahui seberapa jauh efektivitas perusahaan dalam mengelolah dana kasnya guna menghasilkan pendapatan dari penjualan. Hal ini dibutikan dengan adanya penelitian Nurafika dan Almdany (2018) yang menyatakan perputaran kas berpengaruh positif signifikan terhadap profitabilitas pada perusahaan semen.

Komponen modal kerja yang lain dalam penelitian ini adalah persediaan, juga merupakan elemen utama dari modal kerja, karena jumlahnya cukup besar dalam suatu perusahaan, jenis persediaan yang ada dalam perusahaan akan tergantung dari jenis perusahaan (Wiagustini, 2010:148). Persediaan merupakan salah satu pos dari aktiva lancar yang penting karena persediaan merupakan unsur yang aktif dalam operasi BUMDes yang terus menerus diperoleh, diubah, dan kemudian dijual kepada konsumen. Perputaran persediaan merupakan salah satu hal yang harus diperhatikan oleh pihak BUMDes dalam operasi dari BUMDes itu sendiri. Persediaan harus dikelola dengan baik karena persediaan yang optimal dapat meningkatkan efektifitas perusahaan sehingga meningkatkan keuntungan yang diperoleh perusahaan. Semakin tinggi rasio perputaran persediaan menunjukkan bahwa modal kerja yang tertanam dalam persediaan barang dagang semakin kecil dan hal ini berarti semkain baik bagi perusahaan karena lamanya penjualan persediaan barang dagang semakin cepat atau dengan kata lain bahwa persediaan barang dagang dapat dijual dalam jangka waktu yang relatif semakin singkat sehingga perusahaan tidak perlu lama menunggu dananya yang tertanam dalam persediaan barang dagang untuk dapat dicairkan menjadi uang kas. 
Pernyataan ini juga didukung dengan hasil penelitian dari Tirtajaya (2016) perputaran persediaan berpenaruh positif tetapi tidak signifikan terhadap profitabilitas.

Perputaran Total Aset (Perputaran Total Aset) merupakan kecepatan berputarnya aktiva usaha dalam suatu periode tertentu yang diperoleh dengan membandingkan penjualan dengan total aktiva. Jika perputaran aktivanya naik maka profitabilitas akan meningkat. Rasio perputaran total aktiva yang menunjukan kegiatan perusahaan dalam menggunakan keseluruhan aset untuk menciptakan penjualan. Semakin cepat tingkat perputaran aktiva suatu perusahaan maka laba bersih yang dihasilkan akan semakin meningkat, karena perusahaan tersebut sudah dapat memanfaatkan seluruh total aktiva tersebut untuk meningkatkan penjualan yang berpengaruh terhadap pendapatan perusahaan, karena pendapatan akan meningkat jika kondisi biaya dan pajak yang dikeluarkan tetap. Sehingga jika kondisi seperti itu maka dapat meningkatkan laba bersih perusahaan. Pernyataan ini didukung juga dengan hasil penelitian yang menyatakan bahwa Barus dan Leliani (2017) perputaran total asset berpengaruh signifikan dan parsial terhadap profitabilitas.

Berdasarkan data yang diperoleh dari Dinas Pemberdayaan Mayarakat dan Desa sampai dengan tahun 2021 sudah terbentuk 126 BUMDes di Kabupaten Buleleng. Dari penilaian terhadap 126 BUMDes yang sudah terbentuk, BUMDes di Kabupaten Buleleng diklasifikasikan BUMDes Maju, BUMDes Berkembang, BUMDes Tumbuh dan BUMDes Dasar.

Ada beberapa permasalahan yag perlu dikasi yaitu pertama,bagaimana pengaruh dari perputaran modal kerja terhadap profitabilitas dari BUMDes sehingga mampu meningkatkan pendapatan asli desa. Kedua, bagaimana pengaruh dari perputaran kas terhadap profitabilitas dari BUMDes sehingga mampu meningkatkan pendapatan asli desa. Ketiga, bagaimana pengaruh dari perputaran persediaan terhadap profitabilitas dari BUMDes sehingga mampu meningkatkan pendapatan asli desa. Keempat, bagaimana pengaruh dari perputaran total aset dalam terhadap profitabilitas dari BUMDes sehingga mampu meningkatkan pendapatan asli desa. Kelima, bagaimana pengaruh perputaran modal kerja, perputaran kas, perputaran persediaan, dan perputaran total aset dalam terhadap profitabilitas dari BUMDes sehingga mampu meningkatkan pendapatan asli desa.

Dalam rangka menjawab permasalahan tersebut penelitian ini bertujuan untuk membuktikan secara empiris pengaruh tingkat perputaran modal kerja, perputaran kas, perputaran persediaan, dan perputaran total asset terhadap profitabilitas Badan Usaha Milik Desa di Kabupaten Buleleng periode 2019-2020.

Hasil dari penelitian ini sangat bermanfaat yakni : Pertama, manfaat teoritis yaitu dapat menjadi bahan referensi dan kajian untuk penelitian selanjutnya serta diharapkan dapat mengembangkan ilmu akuntansi secara lebih lanjut khususnya sehubungan dengan pengaruh tingkat perputaran modal kerja, perputaran kas, perputaran persediaan dan perputaran total asset terhadap profitabilitas Badan Usaha Milik Desa di Kabupaten Buleleng. Kedua, maanfaat praktis yakni dapat menjadi bahan pertimabngan bagi Badan Usaha Milik Desa dalam meningkatkan laba atau profitabilitas untuk meningkatkan pendapatan asli desa.

\section{Metode}

Penelitian ini dilakukan pada Badan Usaha Milik Desa (BUMDes) di Kabupaten Buleleng. Penelitian ini menggunakan pendekatan kuantitatif karena data yang digunakan berbentuk angka, pengumpulan data dilakukan melalui dokumentasi dan akan dianalisis menggunakan bantuan program SPSS. Berdasarkan sumbernya, penelitian ini menggunakan jenis data sekunder. Data sekunder umumnya berupa bukti, catatan atau laporan historis yang telah tersusun dalam arsip (data dokumenter) yang dipublikasikan dan yang tidak dipublikasikan. Data sekunder digunakan dalam penelitian ini adalah data mengenai laporan 
keuangan dan laporan-laporan yang dibuat oleh Badan Usaha Milik Desa (BUMDes) di Kabupaten Buleleng periode tahun 2019-2020.

Populasi dalam penelitian ini adalah seluruh Badan Usaha Milik Desa yag menyetorkan laporan keuangan kepada Dinas Pemberdayaan Masyarakat dan Desa Kabupaten Buleleng. Berdasarkan data Dinas Pemberdayaan Masyarakat dan Desa terdapat 126 BUMDes yang tersebar diseluruh Kabupaten Bueleng. Sementara jumlah sampel yang digunakan dalam penelitian ini sebayak 16 BUMDes. Teknik pengambilan sampel dalam penelitian ini menggunakan teknik purposive sampling.

Adapun kriteria atau pertimbangan sampel yang digunakan oleh penulis adalah : pertama, BUMDes yang telah terdaftar pada Dinas Koperasi Perindustrian dan Perdagangan Kabupaten Buleleng pada tahun 2010-2015. Kedua, BUMDes memiliki unit usaha seperti pertokoan, pasar desa dan simpan pinjam. Ketiga, BUMDes memiliki laporan keuangan lengkap seperti Laporan Neraca, Laporan Laba Rugi, Laporan Penjualan dan Pembelian serta Laporan kegiatan dari BUMDes pada periode 2019-2020. Keempat, BUMDes yang memberikan izin untuk laporan keuangannya digunakan sebagai bahan penelitian

Variable bebas (dependent variables) dalam penelitian ini adalah tingkat perputaran modal kerja, perputaran kas, perputaran persediaan dan perputaran total asset. Sedangkan variable terikat (independent variable) dalam penelitian ini adalah profitabilitas.

Analisis data yang digunakan adalah uji asumsi klasik yang terdiri dari uji normalitas, uji multikolinraritas, uji autokorelasi dan uji heterokedastisitas. Uji hipotesis menggunakan uji regresi linear berganda, uji hipotesis (Uji T), uji simultan (Uji F) dan uji koefesien determinasi (R2).

\section{Hasil dan Pembahasan}

Data yang digunakan dalam penelitian ini sebanyak 32 data, yang diperoleh dari Dinas Pemberdayaan Masyarakat dan Desa yang terdiri dari 16 BUMDes di Kabupaten Buleleng selama dua periode pengamatan dari tahun 2019-2020. Penelitian ini menggunakan beberapa variable penelitian diantaranya yaitu variable independent perputaran modal kerja (X1), perputaran kas (X2), perputaran persediaan (X3), perputaran total asset (X4) dan variable dependen profitabilias (Y).

Berdasarkan hasil pengujian statistic deskriptif menunjukkan bahwa bahwa untuk variable profitabilitas memiliki nilai rata-rata (mean) adalah 3.3197. Standar deviasi adalah 1,86822. Nilai rata-rata profitabilitas lebih kecil dibandingkan standar deviasinya dengan demikian penyebaran data untuk variable profitabilitas dalam penelitian ini adalah merata dan tidak ada perbedaan tinggi antara data yang satu dengan data yang lainnya. Nilai minimum Profitabilitas adalah $0,10 \%$. Nilai maximum profitabilitas adalah 6,92\%.

Data variable perputaran modal kerja nilai rata-rata (mean) pada perputaran modal kerja adalah $1,7134 \%$ dengan standar deviasi sebesar 0,50142 . Nilai rata-rata perputaran modal kerja lebih kecil dibandingkan standar deviasinya dengan demikian penyebaran data untuk variable perputaran modal kerja dalam penelitian ini adalah merata dan tidak ada perbedaan tinggi antara data yang satu dengan data yang lainnya. Nilai minimum pada perputaran modal kerja ialah sebesar $0,50 \%$ dan nilai maximumnya adalah $2,57 \%$.

Data variable perputaran kas nilai rata-rata pada perputaran kas ialah sebesar $0,7181 \%$ dengan standar deviasi sebesar 0,87959. Nilai rata-rata perputaran kas lebih besar dibandingkan standar deviasinya dengan demikian penyebaran data untuk variable perputaran kas dalam penelitian ini adalah tidak merata dan ada perbedaan tinggi antara data yang satu dengan data yang lainnya.Nilai minimum perputaran kas adalah $0,02 \%$ dengan nilai maximum sebesar 3,13\%. 
Data variable perputaran persediaan nilai rata-rata (mean) pada perputaran persediaan adalah $0,8400 \%$ dengan standar deviasi sebesar 0,84100 . Nilai rata-rata perputaran persediaan lebih kecil dibandingkan standar deviasinya dengan demikian penyebaran data untuk variable perputaran persediaan dalam penelitian ini adalah tidak merata dan ada perbedaan tinggi antara data yang satu dengan data yang lainnya. Nilai minimum perputaran persediaan yaitu $0,00 \%$ dan nilai maximum yaitu sebesar $2,95 \%$.

Data variable perputaran total asset nilai rata- rata perputaran total asset adalah 0,0275\% dengan standar deviasi 0,02328. Nilai rata-rata perputaran total asset lebih kecil dibandingkan standar deviasinya dengan demikian penyebaran data untuk variable perputaran total asset dalam penelitian ini adalah merata dan tidak ada perbedaan tinggi antara data yang satu dengan data yang lainnya. Nilai minimum perputaran total asset adalah $0,00 \%$ dan nilai maximum nya adalah $0,09 \%$.

Hasil uji normalitas menunjukkan bahwa nilai Kolmogorov-Smirnov sebesar 0,200 dan tidak signifikan pada $0,050(0,200>0,050)$ menunjukkanbahwa residual terdistribusi secara normal dan model regrsi diatas dapat diterima untuk dilakukan analisisn ditahap selanjutnya.

Hasil uji multikolonieritas menunjukkan bahwa nilai VIF dan nilai tolerance masingmasing variable lebih besar dari 10 persen atai 0,10. Demikian juga dengan nilai VIF masingmasing variable lebih kecil dari 10. Nilai tolerance untuk variable tingkat perputaran modal kerja sebesar 0,967 > 0,10 dan nilai VIF sebesar 1,034 < 10, sehingga variable perputaran modal kerja dinyatakan tidak terjadi gejala multikolonearitas. Nilai tolerance untuk variable tingkat perputaran kas sebesar 0,758 > 0,10 dan nilai VIF sebesar 1,237 < 10, sehingga variable perputaran kas dinyatakan tidak terjadi gejala multikolonearitas. Nilai tolerance untuk variable tingkat perputaran persediaan sebesar 0,515>0,10 dan nilai VIF sebesar $1,941<10$, sehingga variable perputaran persediaan dinyatakan tidak terjadi gejala multikolonearitas. Nilai tolerance untuk variable tingkat perputaran total asset sebesar 0,618 $>0,10$ dan nilai VIF sebesar 1,671 < 10, sehingga variable perputaran total asset dinyatakan tidak terjadi gejala multikolonearitas.

Hasil uji autokorelasi dengan signifikan 0,05 atau 5\% dengan jumlah sampel 32, dan jumlah variable independen dalah 5, maka diperoleh table untuk dL adalah $=1,1769$ dan $\mathrm{dU}$ adalah $=1,7323$. Sedangkan besarnya DW adalah 1,895 . Nilai DW 1,895 berada diantara $\mathrm{dU}<\mathrm{DW}<4$-dU maka menjadi $1,7323<1,895<2,2677$, maka dapat disimpulkan bahwa penelitian ini bebas dari masalah autokorelasi.

Tabel 1. Hasil uji heterokedastisitas

\begin{tabular}{|c|c|c|c|c|c|c|}
\hline \multicolumn{7}{|c|}{ Coefficients $^{\mathrm{a}}$} \\
\hline & & Unstandardize & oefficients & $\begin{array}{l}\text { Standardized } \\
\text { Coefficients }\end{array}$ & & \\
\hline \multicolumn{2}{|c|}{ Model } & $\mathrm{B}$ & Std. Error & Beta & $\mathrm{t}$ & Sig. \\
\hline \multirow[t]{5}{*}{1} & (Constant) & 1.455 & .610 & & 2.387 & .024 \\
\hline & Modal Kerja & .037 & .318 & .021 & .115 & .909 \\
\hline & Kas & .108 & .244 & .110 & .443 & .661 \\
\hline & Persediaan & -.358 & .207 & -.351 & -1.726 & .096 \\
\hline & Total Aset & -4.407 & 8.375 & -.120 & -.526 & .603 \\
\hline
\end{tabular}

a. Dependent Variable: RES2

Uji heteroskedastisitas dengan model glesjer pada gambar 1 diatas menunjukkan nilai signifikan variable perputaran modal kerja $(0,909)$, perputaran kas $(0,661)$, perputaran persediaan $(0,096)$ dan perputaran total asset $(0,603)$ lebih besar dari 0,050 sehingga tidak terjadi gejala heteroskedastisitas dalam penelitian ini. 
Pengajuan hipotesisi yang dilakukan dalam penelitian ini menggunakan analisis linier berganda yang dihitung memakai program Statistical Package for The Social Sciences (SPSS) 25. Tujuan digunakannya analisis regresi linier berganda adalah untuk mengetahui pengaruh tingkat perpuaran modal kerja, perputaran kas, perputaran persediaan dan perputaran total asset terhadap profitabilitas badan usaha milik desa di Kabupaten Buleleng periode 2019-2020. Hasil dari analisis regresi linier berganda dalam penelitian ini dapat disajikan atau dilihat pada table 2 .

Tabel 2. Hasil Uji Hipotesis

\begin{tabular}{|c|c|c|c|c|c|c|c|c|}
\hline \multicolumn{9}{|c|}{ Coefficients $^{a}$} \\
\hline & & $\begin{array}{r}\text { Unstand } \\
\text { Coeffi }\end{array}$ & $\begin{array}{l}\text { rdized } \\
\text { ients }\end{array}$ & $\begin{array}{l}\text { Standardized } \\
\text { Coefficients }\end{array}$ & & & Collinearity & atistics \\
\hline \multicolumn{2}{|c|}{ Model } & $\mathrm{B}$ & Std. Error & Beta & $\mathrm{t}$ & Sig. & Tolerance & VIF \\
\hline \multirow[t]{5}{*}{1} & (Constant) & 4.534 & 1.098 & & 4.129 & .000 & & \\
\hline & Modal Kerja & -.889 & .572 & -.238 & -1.553 & .132 & .967 & 1.034 \\
\hline & Kas & 1.157 & .447 & .545 & 2.590 & .015 & .515 & 1.941 \\
\hline & Persediaan & .542 & .379 & .244 & 1.432 & .164 & .785 & 1.273 \\
\hline & Total Aset & -35.588 & 15.413 & -.443 & -2.309 & .029 & .618 & 1.617 \\
\hline
\end{tabular}
berikut :

Berdasarkan table tersebut dapat disusun persamaan regresi linier berganda sebagai

$$
\begin{aligned}
& \mathrm{Y}=\alpha+\beta 1 \mathrm{X} 1+\beta 2 \mathrm{X} 2+\beta 3 \mathrm{X} 3+\beta 4 \mathrm{X} 4+\mathrm{e} \\
& \text { Profitabilitas }=4,534-0,889 \mathrm{X} 1+1,157 \mathrm{X} 2+0,542 \mathrm{X} 3-35,588 \mathrm{X} 4+\mathrm{e}
\end{aligned}
$$

Berdasarkan persamaan regresi linier berganda tersebut dapat diartikan koefesienkoefesiennya adalah sebagai berikut : Adapun interpretasi pada persamaan diatas diantaranya adalah :

Nilai konstanta positif menunjukkan pengaruh positif yang artinya bahwa jika variable perputaran modal kerja, perputaran kas, perputaran persediaan dan perputaran total asset dianggap konstan maka profitabilitas akan meningkat sebesar 4,534

Koefesien regresi pada variable perputaran modal kerja yaitu sebesar -0,889 dimana akan menunjukkan bahwa apabila jika nilai tingkat perputaran modal kerja (X1) meningkat 1 satuan sedangkan variable yang lain konstan, maka variable perputaran modal kerja akan diprediksi akan menurun.

Koefesien regresi pada variable perputaran kas yaitu sebesar 1,157 menunjukkan bahwa apabila persepsi mengenai variable perputaran kas (2) meningkat 1 satuan sedangkan variable yang lain konstan maka perputaran kas akan diprediksi akan meningkat sebesar 1,157 .

Koefesien regresi pada variable perputaran persediaan yaitu sebesar 0,542 menunjukkan bahwa apabila persepsi mengenai variable perputaran persediaan (X3) meningkat 1 satuan sedangkan variable lain konstan maka perputaran persediaan akan diprediksi akan meningkat sebesar 0,542.

Koefesien regresi variable perputaran total asset yaitu sebesar -35,588 menunjukkan bahwa apabila persepsi mengenai perputaran total asset (X4) meningkat 1 satuan sedangkan variable lain konstan, maka profitabilitas diprediksi akan menurun sebesar 35,588.

Berdasarkan hasil uji t terhadap variable tingkat perputaran modal kerja (X1) Dalam melakukan uji t test dilihat hasil pengujian nilai signifikannya adalah 0,132 yang berarti diatas tingkat signifikasi sebesar 0,050. Hasil ini berarti bahwa tingkat perputaran modal kerja berpengaruh negatif tidak signifikan terhadap profitabilitas, sehingga hipotesis pertama 
yang menyatakan perputaran modal kerja berpengaruh positif pada tingkat profitabilitas dalam meningkatkan pendapatan asli desa ditolak.

Hasil uji t terhadap variable tingkat perputaran kas (X2) Dalam uji t test dapat dilihat pengujian menunjukkan nilai signifikannya adalah 0,015 atau dibawah tingkat hasil signifikasi 0,050 . Hal ini berarti bahwa tingkat perputaran kas berpengaruh positif signifikan terhadap profitabilitas, sehingga hipotesis kedua yang menyatakan perputaran kas berpengaruh positif dan tidak signifikan terhadap profitabilitas diterima.

Hasil uji t terhadap variable tingkat perputaran persediaan (X3) Dalam uji t test dilihat hasil pengujian menujukkan nilai signifikasinya adalah 0,164 yang berarti diatas dari tingkat signifikasinya 0,050 . Hal ini berarti bahwa tingkat perputaran persediaan berpengaruh positif tidak signifikan, sehingga hasil dari hipotesis ketiga yang menyatakan perputaran persediaan berpengaruh positif terhadap profitabilitas ditolak.

Hasil uji t terhadap variable tingkat perputaran total asset (x4) Dalam uji t test dapat dilihat hasil pengujian menunjukkan nilai signifikasinya adalah 0,029 atau dibawah tingkat signifikasinya 0,050 . Hal ini berarti bahwa tingkat perputaran total asset berpengaruh negatif signifikan terhadap profitabilitas, sehingga hasil dari hipotesis keempat yang menyatakan perputaran total asset berpengaruh positif terhadap profitabilitas diterima.

Berdasarkan hasil uji $\mathrm{F}$ diketahui bahwa secara bersama-sama variable signifikan terhadap variable dependen. Niilai $\mathrm{F}$ hitung dari model penelitian adalah 4,212 dengan nilai signifikan terbesar 0,009 yang berarti lebih kecil dibandingkan nilai signifikasinya 0,050. Hal ini berarti bahwa model regresi dapat secara simultan mempengaruhi antara variable perputaran modal kerja, perputaran kas, perputaran persediaan dan perputaran total asset terhadap profitabilitas, sehingga hipotesis kelima yang menyatakan perputaran modal kerja, perputaran kas, perputaran persediaan, dan perputaran total asset berpengaruh secara simultan terhadap profitabilitas dapat diterima.

Bedasarkan hasil output SPSS dapat diketahui bahwa dari hasil perhitungan nilai koefesien determinasi (Adjusted R Square) pada mosel diperoleh 0,293. Hal ini berarti sebesar 29,3\% profitabilitas dapat diprediksi dari variable perputaran modal kerja, perputaran kas, perputaran persediaan dan perputaran total asset.

\section{Pengaruh Perputaran Modal Kerja Terhadap Profitabilitas}

Hasil penelitian berarti bahwa tingkat perputaran modal kerja berpengaruh negatif tidak signifikan, sehingga hipotesisi pertama yang menyatakan perputaran modal kerja berpengaruh positif pada tingkat profitabilitas dalam meningkatkan pendapatan asli desa ditolak. Hasil pada pengujian meunjukkan bahwa penurunnya tingkat profitabilitas akibat perputaran modal kerja tidak dapat diukur melalui tinggi rendahnya tingkat perputaran modal kerja karena yang mungkin dikarenakan pihak BUMDes di Kabupaten Buleleng kurang efektif dalam mengelola modal kerja yang dimiliki, Hal ini diduga dikarenakan pada saat situasi pandemi Covid-19, banyak program kredit lunak dengan bunga rendah yang ditawarkan lembaga keuangan lainnya, sehingga banyak masyarakat yang memilih kredit dimaksud, untuk digunakan melunasi utangnya di BUMDes, dengan asumsi adanya perbedaan tingkat suku bunga yang ditawarkan lembaga keuangan lain lebih rendah dibanding BUMDes.

Dalam penelitian ini, mendapatkan sebuah hasil dimana perputaran modal kerja tidak berpengaruh secara signifikan terhadap profitabilitas. Namun hasil penelitian ini bertolak belakang dengan hasil yang dikemukakan oleh Dwiyanthi dan Sudiartha (2017) yang mendapatkan hasil perputaran modal kerja berpengaruh secara positif dan signifikan terhadap profitabilitas. Nopiana (2016) tingkat perputaran modal kerja berpengaruh positif dan 
signifikan terhadap profitabilitas, Natalia, dkk (2016) perputaran modal kerja berpengaruh positif terhadap ROA.

\section{Pengaruh Perputaran Kas Terhadap Profitabilitas}

Hasil penelitian berarti bahwa tingkat perputaran kas berpengaruh signifikan positif terhadap profitabilitas, sehingga hipotesis kedua yang menyatakan perputaran kas berpengaruh positif dan tidak signifikan terhadap profitabilitas diterima. Dengan demikian dapat disimpulkan semakin banyak penjualan yang dapat diperoleh BUMDes untuk setiap perputaran kas selama satu periode dapat meningkatkan profitabilitas yang tinggi. Semakin tinggi perputaran kas ini akan semakin baik, yang artinya penggunaan kas tersebut sudah efisien dan keuntungan yang diperoleh akan semakin besar.

Penelitian ini mendapatkan hasil perputaran kas berpengaruh secara signifikan terhadap profitabilitas dan pernyataan ini juga sejalan dengan adanya penelitian dari Nurafika dan Almdany (2018) yang menyatakan perputaran kas berpengaruh positif signifikan terhadap profitabilitas pada perusahaan semen.

\section{Pengaruh Perputaran Persediaan Terhadap Profitabilitas}

Hasil penelitian berarti bahwa tingkat perputaran persediaan berpengaruh positif tidak signifikan, sehingga hasil dari hipotesis ketiga yang menyatakan perputaran persediaan berpengaruh positif terhadap profitabilitas ditolak. Hasil dari penelitian ini menunjukkan apabila nilai perputaran persediaan tidak berpengaruh terhadap profitabilitas, dimana perputaran persediaan dikatakan demikian dikarenakan dimasa pandemi Covid-19 ini menurunkan niat belanja dari masyarakat, sehingga persediaan yang ada pada masing-masing BUMDes mengalami penumpukan persediaan atau over investment dan ini merupakan hal yang tidak baik karena akan memperbesar resiko kerugian seperti penumpukan barang persediaan, penurunan harga barang, bertambahnya biaya penyimpanan dan pemeliharaan persediaan sehingga menyebabkan penurunan dari profitabilitas.

Hasil penelitian ini sejalan dengan penelitian yang dilakukan oleh Suprihartini dan Nasser (2016); Natalia dkk (2016); Arianti dan Rusnaeni (2018) perputaran persediaan terbukti tidak memiliki pengaruh yang signifikan terhadap profitabilitas..

\section{Pengaruh Perputaran Total Aset Terhadap Profitabilitas}

Hal penelitian berarti bahwa tingkat perputaran total asset berpengaruh negative signifikan terhadap profitabilitas, sehingga hasil dari hipotesis keempat yang menyatakan perputaran total asset berpengaruh positif terhadap profitabilitas diterima.

Hasil penelitian ini menunjukkan bahwa perputaran total asset yang ada di BUMDes di Kabupaten Buleleng berpengaruh signifikan terhadap profitabilitas yang berarti sudah berputar lebih cepat dalam periode tertentu. Dengan begitu BUMDes sudah mengelola asset yang dimiliki secara efektif dan efesien. Kenaikan pendapatan dapat menaikkan laba bersih BUMDes. Namun perputaran total asset memiliki hubungan yang negatif terhadap profitabilitas dikarenakan total asset yang dimiliki BUMDes lebih besar dibandingkan jumlah penjualan yang terjadi pada setiap tahunnya. Hasil penelitian ini juga sejalan dengan hasil penelitian yang dilakukan oleh Barus dan Leliani (2017) perputaran total asset berpengaruh signifikan dan parsial terhadap profitabilitas. Namun bertolak belakang dengan penelitian yang dilakukan oleh Sefiani (2016) yang menyatakan bahwa perputaran total asset tidak berpengaruh secara signifikan terhadap profitabilitas. 


\section{Simpulan dan Saran}

Berdasarkan uraian teori dan hasil yang telah dilakukan dengan uji statistic deskritif, uji asumsi klasik, dan uji hipotesis menggunakan analisis linier berganda antara perputaran modal kerja, perputaran kas, perputaran persediaan dan perputaran total asset terhadap profitabilitas pada BUMDes di Kabupaten Buleleng pada periode 2019-2020 maka dapat diambil kesimpulan yaitu Pertama, perputaran modal kerja berpengaruh secara negative tidak signfikan terhadap profitabilitas pada Badan Usaha Milik Desa di Kabupaten Buleleng pada periode 2019-2020, Kedua, perputaran kas berpengaruh positif signifikan terhadap profitabilitas pada Badan Usaha Milik Desa di Kabupaten Buleleng pada periode 2019-2020, Ketiga, perputaran persediaan berpengaruh positif tidak signifikan terhadap profitabilitas pada Badan Usaha Milik Desa di Kabupaten Buleleng pada periode 2019-2020, Keempat, perputaran total asset berpengaruh negative signifikan terhadap profitabilitas Badan Usaha Milik Desa di Kabupaten Buleleng pada periode 2019-2020, Kelima, pengaruh perputaran modal kerja, perputaran kas, perputaran persediaan dan perputaran total asset berpengaruh simultan terhadap profitabilitas Badan Usaha Milik Desa di Kabupateng Buleleng pada periode 2019-2020.

Berdasarkan hasil penelitian yang telah dilakukan, maka penulis menyarankan beberapa hal mengenaik pengaruh perputaran modal kerja, perputaran kas, perputaran persediaan dan perputaran total asset terhadap profitabilitas yaitu BUMDes perlu lebih memperhatikan manajemen modal kerjanya sehingga menjadi lebih baik dengan cara memaksimalkan penjualan, Pihak BUMDes udah memaksimalkan penggunaan kas secara efektif dan efesien sehingga harus dipertahankan dan ditingkatkan kembali, Perputaran Persediaan, BUMDes perlu mengevaluasi dan memperhatikan perputaran dari persediaan agar menghasilkan perputaran persediaan yang baik, dengan cara BUMDes harus perlu memperhatikan batasan maksimum dan minimum jumlah persediaan yang tersedia didalam gudang, Perputaran Total Asset, perlu adanya aktivias penggunaan asset BUMDes yang ditingkatkan dimasa yang akan datang dengan cara meningkatkan rasio perputaran piutang dengan meningkatkan pembayaran piutang sehingga perputarannya semakin cepat dan meminimalisir pengeluaran biaya yang tidak diperlukan sehingga nantinya mampu meningkatkan profitabilitas dari BUMDes, Profitabilitas, Pihak BUMDes seharusnya meningkatkan kinerja dari manajemen karena kepiawaian pengelola sangat menentukan keberhasilan BUMDes. Sehingga pihak BUMDes mampu mengevaluasi dan mengidentifikasi factor-faktor yang menyebabkan penurunan dengan cara menjaga agar harga pokok penjualan tetap efisien dan berusaha agar pendapatan diperoleh dari penjualan meningkat, meningkatkan efesiensi dan efektivitas modal yang diinvestasikan, berusaha untuk menekan biaya operasional seefesien mungkin agar dapat meningkatkan penjualan. Adapun saran untuk pemerintah hendaknya mengawasi manajemen dan cara pengelolaan BUMDes secara rutin untuk melihat perkembangan BUMDes di masing-masing desa, Pemerintah hendaknya dapat memberdayakan BUMDes dengan menjadikan BUMDes sebagai mitra kerja dalam pemenuhan keperluan perkantoran atau kegiatan lainnya, dan bagi peneliti selanjutnya yang akan meneliti hal ikhwal yang terkait dengan profitabilitas, diharapkan agar mencari faktor lain yang dapat atau lebih signifikan mempengaruhi tingkat profitabilitas, diharapkan periode penelitian agar lebih lama, sehingga bisa melihat perkembangan dari BUMDes di Kabupaten Buleleng, serta perlu juga meneliti pengaruh eksternal yang sering mengintervensi keberadaan BUMDes.

\section{Daftar Pustaka}

Barus, A. (2017). Analisis Faktor-Faktor yang Mempengaruhi Profitabilitas pada Perusahaan Manufaktur yang Terdaftar di Bursa Efek Indonesia. JWEM (Jurnal Wira Ekonomi 
Mikroskil), 3(2), 111-121. https://doi.org/https://www.mikroskil.ac.id/

Hery. (2017). Analisis Laporan Keuangan. Grasindo.

Kasmir. (2011). Analisis Laporan Keuangan. Pt. Raja Grafindo Persada.

Kasmir. (2014). Analisis Laporan Keuangan, (1st ed.). PT. Raja Grafindo Persada.

Natalia, K. V., Raharjo, K., \& Supriyanto, A. (2016). Pengaruh Perputaran Modal Kerja, Perputaran Kas Perputaran Piutang Dan Perputaran Persediaan Terhadap Profitabilitas Perusahaan Manufaktur Yang Terdaftar Di BEI Tahun 2011-2015. Jurnal Ilmiah Mahasiswa S1 Akuntansi Universitas Pandanaran, 38(1), 2-7. https://doi.org/https://jurnal.unpand.ac.id/

Nopiana, Y., Herawati, N. T., \& Sulindawati, N. L. G. E. (2016). Pengaruh Tingkat Perputaran Modal Kerja, Perputaran Kas, Perputaran Piutang, Pertumbuhan Jumlah Nasabah, Dan Jumlah Karyawan Terhadap Profitabilitas Koperasi Simpan Pinjam (Ksp) Di Kabupaten Buleleng. E-Journal S1 Akuntansi Universitas Pendidikan Ganesha, 3(1). https://doi.org/https://ejournal.undiksha.ac.id/

Novia Dwiyanthi, D. (2017). Pengaruh Likuiditas dan Perputaran Moda Kerja Fakultas Ekonomi dan Bisnis. Manajemen, 6(9), 4829-4856. https://doi.org/https://media.neliti.com/

Nurafika, R. A. (2018). Pengaruh Perputaran Kas, Perputaran Piutang, Perputaran Persediaan Terhadap Profitabilitas Pada Perusahaan Semen. Jurnal Akuntansi Dan Binsnis : Jurnal Program Studi Akuntansi, 4(1). https://doi.org/10.31289/jab.v4i1.1532

Salampessy, Z. (2011). Pengaruh Dana Alokasi Umum (DAU) dan Pendapatan Asli Daerah (PAD) Terhadap Belanja Daerah. Jurnal Ekonomi Dan Manajemen, 2(1), 19-29. https://doi.org/https://ejournal.unpatti.ac.id/

Sariningsih, N. (2018). Pengaruh Perputaran Kas, Perputaran Piutang Dan Perputaran Persediaan Terhadap Profitabilitas (Studi Kasus Pada Perusahaan Property dan Realestat yang Terdaftar di Bursa Efek Indonesia Periode 2010-2016. Jurnal Buana Akuntansi, $\begin{array}{llll}\text { Universitas Singa } & \text { Kerbangsa }\end{array}$ https://doi.org/https://journal.ubpkarawang.ac.id/

Sefiani, C. Y. K. (2016). Pengaruh Current Ratio, Total Asset Turnover Dan Umur Perusahaan Terhadap Profitabilitas. Ekonomi Dan Akuntansi. https://doi.org/https://docplayer.info/

Supriyadi, Y., \& Fazriani, F. (2015). Pengaruh Modal Kerja Terhadap Tingkat Likuiditas Dan Profitabilitas ( Studi Kasus pada PT Timah, Tbk . dan PT Antam, Tbk .). Jurnal Ilmiah Ranggagading, 11(1), 1-11. https://doi.org/https://www.researchgate.net

Tirtajaya, N. (2016). Pengaruh Perputaran Piutang, Perputaran Persediaan, dan Rasio Lancar Terhadap Profitabilitas Pada Perusahaan Manufaktur Sektor Industri Barang Kosumsi yang Terdaftar Di Bursa Efek Indonesia Periode 2012-2014. Universitas Darma Persada, Jakarta. https://doi.org/https://unsada.e-journal.id/

Wiagustini, N. luh P. (2010). Dasar - Dasar Manajemen Keuangan. (1st ed.). Bali Udayana University Press.

Widyastuti, Y. (2017). Peran Badan Usaha Milik Desa Terhadap Kesejahteraan Masyarakat 
Pengaruh Perputaran Modal Kerja, Perputaran Kas, Perputaran Persediaan dan Perputaran Total Aset Terhadap Tingkat Profitabilitas Badan Usaha Milik Desa untuk Meningkatan Pendapatan Asli Desa Tahun 2019-2020 (Studi pada Badan Usaha Milik Desa Se-Kabupaten Buleleng)

Pujokerto Kec. Trimurjo Kab. Lampung Tengah. Universitas Negeri Raden Intan. https://doi.org/http://repository.radenintan.ac.id/ 